\title{
COMMON E.N.T. PROBLEMS IN CHILDREN
}

\author{
by
}

Dr. P.R. Roj Bhasdarit

M.B.BS, D.LO. (London)

As with all the branches of medicine, our knowledge of the ctolaryngological problems of childhood has greally increased. It is important that otolaryngologists and paediatriciaiss should have a sound knowledge of the problems involved, so that proper treatmeat can be direcied tinely. In this article an attempl has been made to deal with the common ENT problems, mentioning the salient features only.

\section{THE EAR AND MASTOID}

Deafness in Children is seed very frequently. Acquired conductive deafness occurs due to impacted cerumen, impacted foreign body (F.B.), blockage of eustactian tube due to enlarged adenoid and "glue-ear." Acquired perceptive dearness maybe congenital or acquired after birth. Congenital dealness may be complete or partial. It may result due to rubella, kernicierus, congenital syphilis, maternal influenza, acule poliomyclitis and toxaemias of pregnancy. Rubella in early pregnancy prevents or hinders tie notmal development of the crgan of corti. In kerniclerus the peripbetal oryans develop normally but the cochlear unclei in the brain are damaged. There is damage both in the cndorgin and in the neuret elements in congenital syphilis.

Diagnosis of congenital deafness due to syphilis may prescnt difficulty. it is of progressive nature. In the eariy stage VDPL is normally positive, but hecomes negative later. Farly diagocsis and treatment by pericillin arrest the progress of desfness in sone cases.

Acquited post-fuetal perceptive deafness commonly occurs foll-wing meningitis (particulerly meningo-coccal). Deafness is usually a resull of meningo-newitis of the eighin

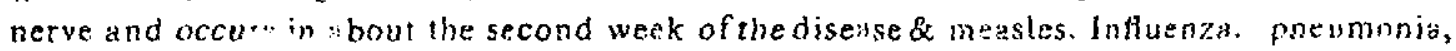
diphtheria, purturss and enteric fever have all been blamed. Trama is a possible cause but a fracture of the ckull likely co cause complete deafness would mosi probably prove fotal. Toxic manifestang of steptonycin. dihydrostreplomycin. neomyein, quinine and

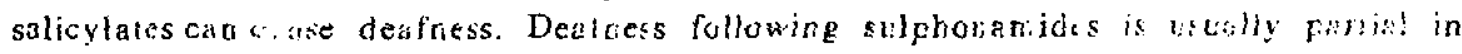
degree and cor uctive in type.

to Consallont ENT Sugron, T.C. Military Hospital, Kathmands. 
Treatment is by correction of defect where possible, speech training, and auditory training with social and general training to teach child to act rormally is his environment. The latter is possible only in spectal school for the deaf.

FURUMCULOSIS OTITIS EXTERHA, DERMATITIS AHD IMPACTED WAX all occur in children but are less frequent as compared to adults. However, the soft tissues swell more rapidly in the child in case of furunculosis.

FOhElG BODY is frequently found. Treament is removal by syringing, or by using special ferceps, or a right angled probe depeoding on the site and nature of the F.B. In some crses post-auicular incision may have to be performed, under $G A$, to remove the F.B. Adequate light is essential. Considerable dexterity is necessary. In unskilled band removal of F.B. from ear is a dangerous procedure. This applies equally when removing impacted wax.

Hairslide, pencil tip, match stick may tear tympanic membrane (T.M.) rreatment is by propbylactic antioiotic therapy, removal of offending agent if left inside. Urder no - cumsiance should the TM be disturbed manually or by local medication.

Simple Acute Otitis Media (AOM) in Infant. Diagnosis is easy if one does not miss ear examination. Treatment is by suitable antibiotics in adequate dose and proper duration. If severe pain and bulging of T.M. is seen myringolomy, under GA and eperating microscope. should be performed. Pus is sent for culure and depending on the culiure report abibiorics should be changed, if neccsary. Proper cleaning of mealus asepuically onces a day is a must. Ho cirops be put in the ear. $0.5 \%$ ephedrine hydrochloride in normal saline drops instillation in the nostals cnoourage cfaring of Enstachiar tubes. Criteria of curs is restoration of normal hearing. If bearifig does not improve with adequate treatment or a low-grade rastoiditis be present cortical mastoidectony is indicated.

"GLUE.EAR" (GEROUS OTITS MEDIA)-could be due to large adenoid and ronsils intertering Eustactian tube opening, or te the resuli of U.R. Trist infection. It could be the sequele of inadequate antibiotic treatment in AOM. The resul is a deaf chitd. Treatment is removal of the cause, myringotomy and ispiration of fluid. Rer eated aspiration may lave to be doce in some cases. These children should be obseivsd al least for a year.

CHRONIC OIITIS HEDIA - is a common condition. There is discharge from the ear frequenlly with associuted deafness. The frst pricciple of treatment is to differentiate whecher the ear is "Safe type" (central perforalion of TM) or "dangerous type" (marginal perforotion with cbolesieatuma formation). The lutter (ype is liable to ceuse intracranial complications. Surge $y$ is necessary in this iypr, the extent depending upon removal of cholesteistoma through the perforation to radical mastoideciomy. In the 'sale type' the principle of treatment is the removal of sources of infection (eg, adenoid removal, treatment of sinus infection), keeping ear dry and clean, and myringoplasty operation after the ear 
has been free of ischarge at least for six months. A dry ear, with perferated TM, is not a normal ear. The operation will preserve normal hearing, and prevent furiber midde ear infection.

Headache, vertigo aud persisting pyrexja are features that may be associated with the development of intracranial complicatious specially in the 'dangerous type.'

Finally, under no circumstance one should advise a patient to put colosse (eg. mercurochrome gentian vollet efc.) eat drepst This will mask the view of 7 .M. and lead to erroncous diagnosis.

\section{NOSE}

CLEFT LIP AHD PALATE-Treatment is by surgery and is often left te plastic surgeon slihougi in palate cases the subsequeot speech trainiog shoulo te sulcivisd by a laryngologis: Befure the age of one, post-operative oedema and a lax ugue nity cuse airway obstrucitin fost-operatively. Repair sbould not be delayed much beynd the time when speech is becun. The idea of repair is therefore, to furnish tbe clild witis an adeguare speech mechnuisro before it starts 10 pronounce words. After the age uf hice post-operalive mortality is low tot thore is increasiugly disappointing speech result The true citerion of success in clef $p$ late surgery is the speech result that is achieved posi-treratively. Hence the ideal time for cleft repair, though disputed, is generaliy thought 10 be between one and three years of is

Post-op-iarive managenent is very important, specially the col: of barrier nursing cannot be overatiotasised.

Iacidance of EPISTAXIS in children is about $t$ wice tiat in aduit. Epistaxis proper is rare below tin: : $g$ : ef three. Local causes of epistaxis are: erosicn of luciles area, traumaaccidental or du: in surgical procedures, acute rhinitis (the common co id), all forms of cbronic rhmitic (simple, allergic, tuberculous, syphilitic), grossly inlected tdeincids, or retention at B. is the nose. General-causing nose-bleed are-vereas congestion (due to beart failure: : Vera canal obstruction); so-called bleeding diseases eg. bremophilia, thrombocyioper.ic murpura, aplastic anaemia, leukaemia and scums; heavy doses of salicylates and quinme; certain acute infections eg typhoid, malaria (cause episiaxis in early stage), and anatemi: (may cause epistaxis in advanced casesj. Diagnosis is obvious.

Treatmeni-jeoeral treatment is rest, nourishment and treatment of underlying blood dyscresi it ther systemic diseases. Local 1 reatment consists in sustained pressuro to the alise nis: ! : bout 10 minules or more. Failing this procedure risal packing is done. However $i$ is whot while to avoid nosal plugging as far as possible to prevent toxic effect of drug and demign to nasal mucosa. The next method is to cauterise the bleeding point. Recurrent efis ixt: eftercauterisation is indication for submucous resection. This must also be avoiges as far as practicable because this operation in children can deform the ultimate exicriol sinpe of nose. and the unsupforted nasal mucosa tends to remain. oedematous. Pist-nas $;$ f plugging and ligature of ethmoidal arteries are rarely vecessary. 
SINUSIIIS-Usually maxillary and ethmoidal sinuses are affected: Examination shows mucopus in nose and nasopharynx witb inflammatory engrargement of the nasal mucosa. Sinus $x$-rays and bacteriological cultures with proof punclures, when necessary, confrm the diagnosis. Treatment consists of improvement of genera] bealth [removal of adenoids and possibly tonsils), full trial of suitable antibiotics antrol lavage with indwelling polythene tubes may all have to be considered.

DEFLECTED. NASAL SEPIUM is uncommon. Ideal age for correction (SMR) is. 14 years.

FOREIGN BODY Recently introduced foreign bodies have only the sympiom of nisal obstruction. Long standing F.B. cause purulent nasal discharge. Diagnosis is by rhinoscopy and $x$-ray. Treatment is removal of the F. B. under proper light.

HASAL POLYP. in children is rare. In children under 10 years, antrochoanal polyp is the usual form. Treatment is by simple removal. Should recurrence take place CaldwelLuc operation is indicated.

NASAL ALLEGY - Alleryy manifestations in the respiratory tract ore very common in children, Asthma is most common manifestation of allergy in infant. Allergic rhinitis is. most commonly seen in school children who may however develop asthma later on. Nasal Siausitis is therefore a common complication of allergy. True hayfever is rare before the age of 10. Diagnosis is by eliciting history properly, besides rbinoscopy and intradermal test. Treatment is by removal of or from causative allergen where possible, eliminaing or reducing child's allergic response by desensitisation, general antiallergic treatment, spray of antihistamines with $0.5 \%$ epbedrine bjdrccbloride in normal saline locally, treat toent of secondary conditious like sepsis, sinusitis, nasal polyp. Rest and sedative in portant. Finally in the treatment the psychological aspect of the disease must be remembered.

\section{THROAT}

Fauces, nasopharynx and larynx are involved by C. DIPHTHERAE. Formation of pseudomembrane at the site of infection, coustitutional symforms and remole cegenerative chaoges due to exotoxios are the characterestic features. Treatment is by A D.S. and by relief of mechanic obstruction to airway by intubation or tracheostomy when occasion demands.

THRUSH/MONILIASIS: Infection by Candida albicans is a common condition particularly in debilitated children and is quite serious. White patches are preduced on the fauces, palate, gums, tongue and buccal mucosa. Palch will demonstrate mycelium ard spores under the microscope. $1 \%$ gentian voilet paint is quite effective. Local spray of Dystatin is specific where available. 
ADEHOID: In children afiection of pharyngeal tonsil or ndenoids are usually important than those of palatine tonsils. The eftect of their eniargenetit on the middic aar, norasl functioning of nose, noimal development of mouth, pulate and tect carnot be overemptasised. Underdevelopment of these parts logether with habilua mouth breathing may lead to further and more dismal effects. Treatmeat of enlarged and infected adenoid is by surgical removal.

TOASILs: Diagnosis and treatment of tonsillitis is easy. The problem arises wlen we bave to consider consillectomy. The views of general practitionets, physicians, laryngolo, is and patiaricians have reacted sbarply agairst whelesale rcmoval of consils and adenoids, due to experience gained as a resull of observing and following vast vumber of cases for jears. In the developed cotntries it bas been a practice, at present, 10 conserve tonsils as far as p-ssible. Tonsils are a past of lymphoid tissue whose main funcricn is thoughi tobe a protective one. Sore throat, and evlarged ionsils alone are no criteria for the removal. With better housing facilities, general improvement in bygic re and nutrition, health cducation and economic welfare, conservation of tonsils this been more or less successful in developed countries.

Recurrent tonsillitis, occuring more than 3 times a year and untonuolled by antibiotics; history of quinsy; enlarged tonsils causing impedence in sreech, breathing and swallowing; carricr state particularly in carriers of resistant strain of slaphylocsurs aureas, diphtheria are some of he indications for consilleclomy. In short, tonsilectomy should not be performed without any real justification.

\section{Laryngeal Stridor}

COHGENITAL LARYMGEAL s!aIDOR is due to. an exaggerated infantile form of laryngeal inlet. Epigiottis, as ic $i$ etal life, is bended backwards jongitndinally on itself. The aryepiglotic folds are also approximaled. This results in lle inle of larys to a cruciate slit. Wheli the child is excited or ciies vulvular effect is produced resultiog inspirafoy stridor. This resolves spontaneously during the second or thitd years of life.

IHFLAMMAROTY OEDEMA, TENACIOUS SPUTUA, PSEUDDPEMBHARE AKD GLCTTK SPASM to varying degree resuit in destruction of larynx. Triese may be caused by coccal intections (strepto and staphylo!, irfleozal or diphtheretical iuficion or

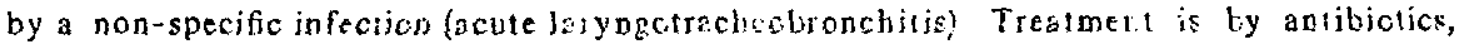
nxygen administration toxygen tent and bumigiferj and timbecstony as sorn as is indicated. Proper oursing is esseritial.

FOREIGN BOOY IMPACTEO IN LARYRX causes strijor by mechanical obsti uctions and by reflex laryngeal spasms. If this phase is survived progressively increasirg serjor ensue due to inftammatory oedema around the F.B. Treatment is by lacleostomy, removal of the F.B. and antibiotics when indicated. 
LARYMGISMUS STAIDULUS is a paroxysmal condition. It usually occurs at night The stridor occurs in children between the ages of $s \mathrm{jx}$ mon!hs and three yers. It is suggested that anoxia due to partial respiratory obstiuction during sleep frobibly withit: irritation of cord by post-nasal discharge precipitate lalyngeal spasm and stritor. This: condition is commonly seen in poorer classes or in a chronically ill, undetnourished or o poorly developed child. They have often sepsis or irritation in the upper respiratoty trect: Treatment is by the improvement of general health and treatment of associated intecticast During ihe attack respiration can be sijulated by splashing cold water and by pulling the tongue forward. The child must get fresti air and the frightesed child must be reassured'.

CYSTS AND NEOPLASMS need be removed eadoscopically. Hatmangioimas andit sarcomas are rare and is treated by radiotherapy. Papillomias which are usually multiple arido infective, tend to recur frequently even afier remcval. Their resclution is spontaneous atih puberty. 